\title{
Language and Law: The Significance of Language Competence in Islamic Legal Theory
}

\section{Mhd. Syahnan, Ja'far, Sahkholid Nasution, Rahmah Fithriani, Waizul Qarni, Isnaini Harahap, and Abd. Mukhsin}

Universitas Islam Negeri Sumatera Utara, Medan, Indonesia

\section{Abstract}

Language and law seem to have either distant or no connection at all. However, in reality these two disciplines are closely interconnected and interrelated, particularly in the perspectives of Islamic legal theory. One's language competence is among the determining factors in comprehending Islamic law. This is because in Islamic legal theory, law is derived from the tenets enshrined in the Qur'an and the Prophetic traditions that require a high standard of Arabic language science. Thus, it can be concluded that language and law are inseparable. Unfortunately, many students

Corresponding Author: Mhd. Syahnan

mhdsyahnan@uinsu.ac.id

Received: 1 July 2019

Accepted: 18 July 2019

Published: 31 July 2019

Publishing services provided by

Knowledge E

(c) Mhd. Syahnan et al. This article is distributed under the terms of the Creative Commons

Attribution License, which

permits unrestricted use and

redistribution provided that the

original author and source are credited.

Selection and Peer-review under the responsibility of the AICLL 2019 Conference Committee.

\section{G OPEN ACCESS} majoring Islamic law still have minor knowledge as well as awareness of the connection between these two disciplines. Regarding this case in hand, the aims of this study are two fold; first, to find out students' awareness of the role of language competence in Islamic legal theory, and second, to investigate the correlation between the awareness with students' competence in Islamic legal theory. This study conducted at the postgraduate program, UIN SU employed a qualitative approach. The data were collected by using questionnaire and in-depth interview. The findings reveal that students' awareness of the significance of language competence is still relatively low. Furthermore, it is also found that the awareness is positively correlated with their competence in Islamic legal theory.

Keywords: competence, Islamic law, legal theory, Arabic, UIN Sumatera Utara

\section{Introduction}

Despite the status of English as "the world's most widely spoken language" (Fithriani, 2018 , p. 741) and the only foreign language compulsorily taught in Indonesian schools (Fithriani, 2017), it does not mean that English becomes the only foreign language class offered in Indonesian educational institutions. Other foreign languages such as French, Japanese, and Arabic are also offered as optional classes in many schools in Indonesia. In case of Arabic language, it has a special status in Islamic-based educational institutions as it is listed as a compulsory subject. The mastery of Arabic is needed in many 
other disciplines include that related to Ushul Fiqh (Islamic legal theory) (Syahnan, 2018). Most people might think that language and law are not connected, yet in Islamic legal theory, the mastery of Arabic is a perquisite for Islamic legal theory which particularly refers to the Qur'an and Hadith from which the main principles of Islamic legal theory are derived (Kamali, 2003). For this reason, language competence is needed by those who study topics related to Islamic law since having high proficiency of language skill, especially Arabic, will deepen their understanding on the subject matter.

Islamic law or Sharia law itself is derived from the religious percepts of Islam, namely; the Qur'an and Hadith. The term Sharia refers to God's divine law, and it is contrasted with Fiqh which refers to human interpretations (Oxford Dictionary Online, 2019). There are four sources of Islamic legal theory or Islamic jurisprudence, namely; the Qur'an, Hadith, ljma and Qiyas. The Qur'an is the most sacred source of law (Hallaq, 2009), and is beyond doubt because it consists the words of Allah SWT. Hadith which is the record of the words, actions and the silent approval of the prophet Muhammad SAW provides more detailed and practical guidance for the information in the Qur'an provided that the Hadith is authentic. ljma or consensus is the agreement of Islamic scholars on a point of view and can elevate law based on possible evidence. Meanwhile, Qiyas or analogical reasoning is the process of deductive analogy by comparing and contrasting the Hadith and Qur'an in order to apply a known injunction (nass) to a new circumstances and create a new injunction (The Oxford Encyclopedia of the Islamic World, 2009). By referring to these sources of sharia, Muslims will be able to know the sharia rulings which may fall into one of the five categories known as "the five decisions" (al-ahkām al-khamsa), namely; mandatory (fard or wājib), recommended (mandūb or mustahabb), neutral (mubāh), reprehensible (makrūh), and forbidden (harām) (Vikør, 2014).

The specific study that discusses about the principles of Islamic jurisprudence explained above is also known as Ușūl al-fiqh (Arabic: أصول الفقه lit. roots of fiqh. This teory is about how the Qur'an and Hadith can be interpreted from the point of linguistics and rhetoric. It also discusses about the methods for establishing the authenticity of hadith (Calder, 2009). In addition, Ușūl al-fiqh allows Muslims to deepen their understanding of religion which will result on their manner of worship and devotion to Allah SWT (the Most High), and enables Muslims to decide whether certain actions are extreme, lenient, well-supported, or just prohibited. However, in studying Ușūl al-fiqh, people are required to have a high proficiency of Arabic skill (Syahnan, 1998).

It is argued that in studying Islamic law, people can refer to the translation of the Qur'an and Hadith without necessarily mastering Arabic, but in fact, it is not enough since the analysis needs the understanding of linguistics and rhetoric in the Qur'an and 
Hadith which are written in Arabic. For example, in understanding the meaning of An Nisa: 29 below, a mere translation is considered not enough for Indonesian people:

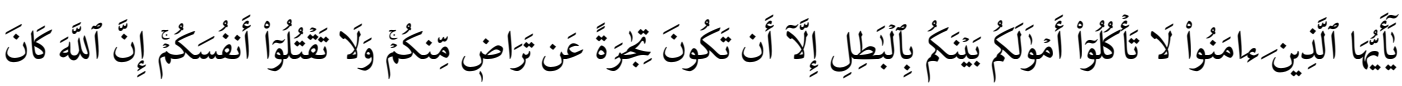

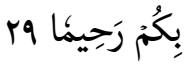

Translation:

O you who believe! do not devour your property among yourselves falsely, except that it be trading by your mutual consent; and do not kill your people; surely Allah is Merciful to you.

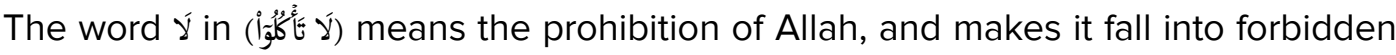

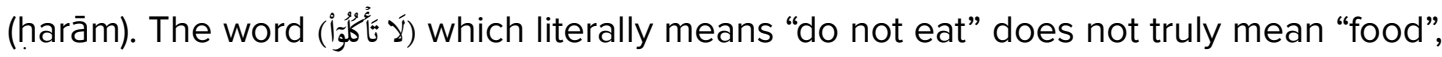
but any kind of transaction.

This theory is studied by the postgraduate students who take Islamic law as their major at the State Islamic University of North Sumatra (UIN SU). These students have varied educational backgrounds. Some of the students are the graduates of Islamic based institutions while the rest are the alumni of conventional institutions. Unfortunately, many students who study Islamic law still have limited understanding of Arabic language and Islamic legal theory even though some of them have learned Arabic before. Based on this phenomenon, it is considered crucial to conduct a research regarding this issue. For this reason, this study aims to find out students' awareness of significance of language competence in Islamic legal theory, and to investigate the correlation between the awareness with the students' competence in Islamic legal theory. By doing this research, the findings of this study will be beneficial to improve students' awareness of studying Arabic and to motivate students in deepening their understanding of Islamic legal theory (Ushul Fiqh).

\section{Literature Review}

\subsection{Language competence}

The study about the role of language competence has been conducted by Ade Dedi Rohayana (2017). In his study, he wanted to see the role of Arabic competence in Ushul Fiqh class given in his university. His research indicates that students should have Arabic skills in order to study Ushul Fiqh because the proposition used in deducing law is based on the Qur'an and Hadith. He also adds that the terminologies in Ushul Fiqh class are mostly taken from Arabic, so the students must learn Arabic in order to successfully understand the nature of Ushul Fiqh. 
Language competence is often defined as linguistic competence which is a system of linguistic knowledge owned by speakers of a language (Noam Chomsky, 1965). Chomsky (1965) states that this competency will enable the native speakers to produce and understand sentences and differentiate grammatical sentences from ungrammatical ones. In other words, people who possess linguistic competence understand the principles and rules of sounds, words, and sentences and are able to recognize when the rules or principles are violated, and the errors they made are "language slips". When these people make this kind of mistake, it means they are tired or distracted, not because they do not know the language.

\subsection{Arabic language}

Indonesia is the largest Muslim population in the world. However, Arabic which is the language used in the Qur'an and Hadith is not the compulsory subject for Indonesian students. This subject is only a mandatory for the students who are studying in Islamic-based institutions like Pesantren (Islamic boarding schools). In relation to this phenomenon, Efrizal (2012) states that Arabic as the language of the Qur'an should be taught in Indonesia as the second language for Muslims.

The postgraduate students who study Islamic Law at the State Islamic University of North Sumatra are expected to have enough understanding of Arabic language to support their learning process, especially when studying Ushul Fiqh (Islamic legal theory). However, in fact, the students show limited understanding of Arabic language. The reason is because not all the students have learned Arabic since some of them did not study in Islamic based institutions. This study tried to explore the students' awareness of language competence, particularly Arabic to support their study in comprehending Islamic legal theory.

\subsection{Islamic law}

It is stated that human should maximize the ability of reasoning given by God so that human can differentiate the right from the wrong, and of course, by referring to the Qur'an and Sunnah (Hadith) of the prophet Muhammad SAW (Hallaq, 2009). The Qur'an, Hadith, ljma and Qiyas are the four sources of Islamic jurisprudence. They are used to know the sharia rulings which might fall into one of the five decisions (alaḥkām al-khamsa): mandatory (farḍ or wājib), recommended (mandūb or mustahabb), 
neutral (mubāh), reprehensible (makrūh), and forbidden (harām) (Schneider, 2014). Muslims believe that they will be rewarded in the afterlife for doing the mandatory and recommended action. (Vikør, 2014). Meanwhile, doing the reprehensible act will not be punished, but should be avoided.

In studying Islamic legal theory or what is often called as Islamic jurisprudence (Ushul Fiqh), Muslims should have good understanding of Arabic language because they cannot depend on the translation of the Qur'an or the Hadith.

\section{Research Method}

This study was conducted at the postgraduate program, State Islamic University North Sumatra (UIN SU) by employing a qualitative approach. The participants were students of Post Graduate Program majoring in Islamic Law. There were 148 students divided into six classes and 75 of them (57 men and 18 women) took part as the participants in this study. The data for this study could be classified into two categories; primary and secondary. The primary data were collected through two instruments, namely: questionnaires and in-depth interviews. All participants were asked to respond to the questionnaire, however, only 10 representing different classes, educational backgrounds, genders, and levels of awareness were invited to the interview session. The data collected from these instruments were analyzed using two methods; frequency count for the data from questionnaire and content analysis for those collected through questionnaire and interview. The secondary data were taken from students' academic records in Qawaid Fiqh (Islamic legal maxim) class. These data were used to obtain participants' competence in Islamic legal theory.

\section{Result and Discussion}

\subsection{Awareness of the significance of language competence}

After analyzing the data, the findings of this study reveal that students' awareness of the significance of language competence in understanding Islamic legal theory is still relatively low, and it can be seen from their responses towards the questionnaires and the interviews conducted. Of the six classes which consists of twenty to twenty-five active postgraduate students at the State Islamic University of North Sumatra, $68 \%$ ( $n=$ 51) of them are not aware of the importance of Arabic language in studying Islamic legal theory. These students are those who graduated from non-Islamic based institution 
or the conventional or secular Law Faculty in their undergraduate degree. Meanwhile, only $29 \%(n=22)$ of the students are aware of the significance of Arabic language in comprehending Islamic legal theory (look at Figure 1 for details).

\section{Demographic of Awareness}

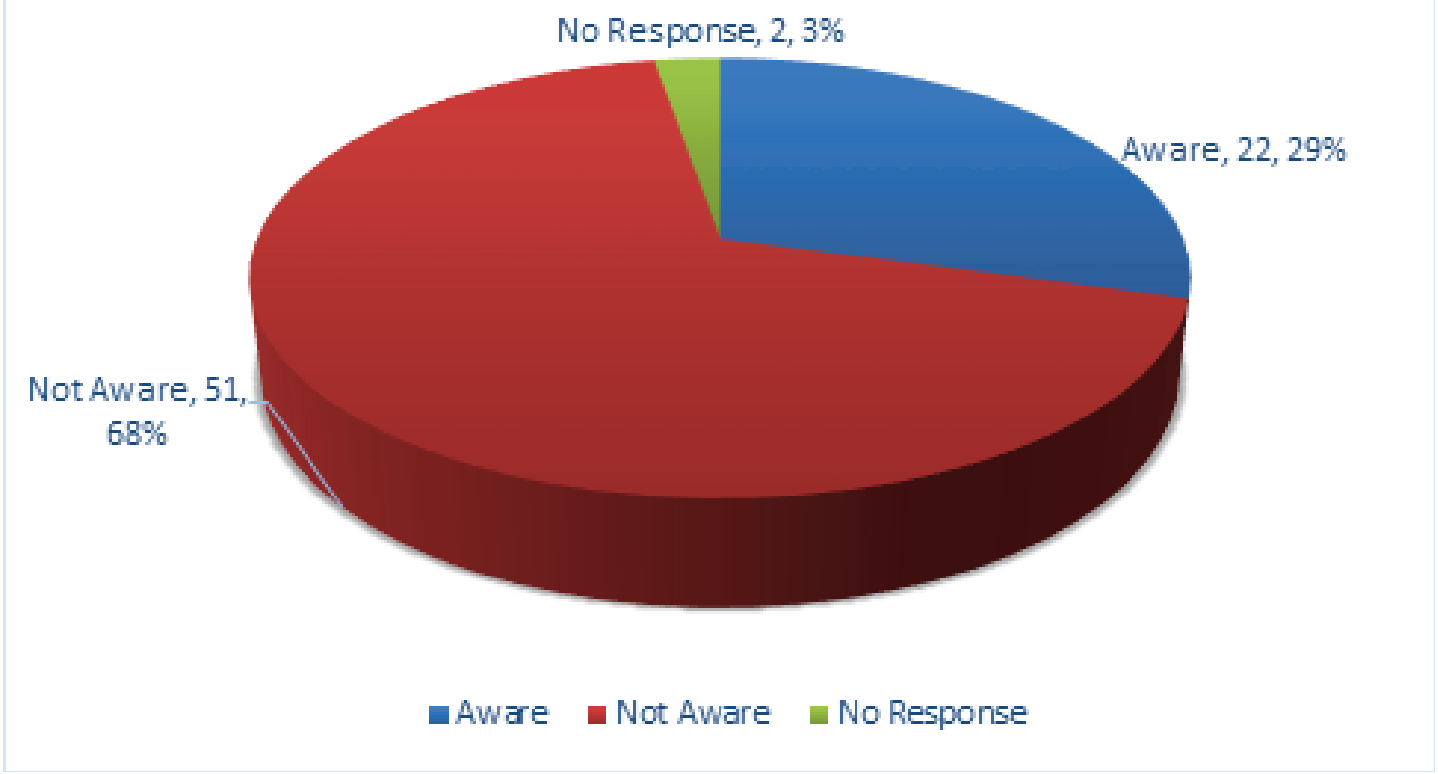

Figure 1:

This result corresponds to students' responses during interview. Eight participants express their opinions indicating that language competence is not necessary in comprehending Islamic legal theory, as seen in excerpts $1 \& 2$.

In my opinion, language competence is not really important in studying Ushul Fiqh since many people have written great books about it. We can also consult to Arabic dictionary and discuss with our friends who have good understanding of Arabic. (Excerpt 1)

I think the competence in Arabic language is is important, for example; Nahwu and Shorof, but in studying Islamic law, in my opinion, even if we don't know Arabic, we can consult to books and dictionary. (Excerpt 2)

Only two participants taking part in the interview session show their awareness of the importance of Arabic language in studying Islamic legal theory (as seen in excerpt 3). One of them graduated from the Middle East, thus have the capability of using Arabic as a means of communication and a tool for Islamic legal theory. 
I think language competence is important, especially Arabic language because when studying about Islamic law, we need to study about the Qur'an and Hadith which are in Arabic. (Excerpt 3)

\subsection{The correlation between awareness of language competence and competence in islamic legal theory}

The second finding of this study reveal that students' awareness of language competence is positively correlated with their competence in Islamic legal theory. It can be seen from the widening gap between those who master Islamic law and those who master conventional law which is resulted in the lack of awareness of the reciprocal roles of the respective side. In addition, when the data related to students' awareness of the significance of language competence is compared to those from students' academic records in Qawaid Fiqh class, the result reveals that the two aspects are positively correlated. This means that students who are aware of the significance of language competence tend to have better understanding of Islamic legal theory. Students who are aware of the significance of language competence score between 90 to 98 in this subject, which is classified as high comprehending of the matter. On the contrary, 40 students from the 'no awareness' group get score below 80 which is classified as low, while the rest get between 80 to 89 which is still classified to have middle comprehension.

\section{Conclusion}

Based on the discussion above, some general and loose trends can be concluded. First, there is a very close connection between postgraduate students 'experience in learning Arabic with their ability to comprehend the discourses of Islamic legal theory. Second, the level of students' Arabic mastery reflected in the standard of their analysis towards Islamic legal related the problems discussed. It means the better the fluency of their Arabic, the higher the quality of the argument and the logic of thinking. Third, the high diversity of students' educational background and the capacity in mastering Arabic should not be seen as the widening gap between those who graduated from conventional university and those who graduated from Islamic based university. Conversely, the two competing scale of the trend should be put in the perspective of reciprocal contribution in making all due effort to seek the feasibility to 
combine the methodology and approach in harmony for the better foreseeable future of academic and humanity alike.

[1] Calder, N. (2009) Law. Legal Thought and Jurisprudence, The Oxford Encyclopedia of the Islamic World. Edited by J. L. Esposito. Oxford: Oxford University Press.

[2] Chomsky, N. (1965) Aspects of the Theory of Syntax. Cambridge: MIT Press.

[3] Efrizal, D. (2012) Improving students' speaking through communicative language teaching method at MTS Ja-Alhaq, Sentot Ali Basa Islamic boarding school of Bengkulu, Indonesia, Journal of Humanities and Social Science, 2(20), 127-134.

[4] Fithriani, R. (2017). Indonesian students' perceptions of written feedback in second language writing (Doctoral Dissertation). Retrieved from https://digitalrepository. unm.edu/educ_llss_etds/87/

[5] Fithriani, R. (2018) 'Discrimination behind NEST and NNEST Dichotomy in ELT Professionalism', in The 1st Annual International Conference on Language and Literature. Medan: KnE Social Sciences, pp. 741-755. doi: DOI 10.18502/kss.v3i4.1982.

[6] Hallaq, W. B. (2009) An Introduction to Islamic Law. Cambridge: Cambridge University Press.

[7] Kamali, M. H. (2003) Principles of Is/amic Jurisprudence. Cambridge: Islamic Text Society.

[8] Oxford Dictionary Online (2019) Sharia. Available at: https://en.oxforddictionaries. com/definition/sharia (Accessed: 30 April 2019).

[9] Rohayana, A. D. (2017) 'Dauru Kafa'ati Thullab Kuliyyah Al-Syari'ah Jami'ah Pekalongan Al- 'Islamiyyah Al-Hukumiyah 'Ala Al-Lughah Al-'Arabiyyah Fi Ta'liimi Ushul Fiqh', Alsinatuna, 3(1). doi: 10.28918.

[10] Schneider, I. (2014) Fiqh, Oxford Encyclopedia of Islam and Politics. Edited by Emad El-Din Shahin. Oxford: Oxford University Press. doi: 10.1093/acref:oiso/9780199739356.001.0001.

[11] Syahnan, M. (1998). The Image of the prophet and the systematization of Ushul al-Fiqh: A study of Al-Shafi'i's risalah. Jurnal Miqat, 103, 44-50.

[12] Syahnan, M. (2018) Hukum Islam dalam Bingkai Transdisipliner. Medan: Perdana Publishing, 2018.

[13] The Oxford Encyclopedia of the Islamic World (2009) Usūl alfiqh. Edited by J. L. Esposito. Oxford: Oxford University Press. doi: 10.1093/acref/9780195305135.001.0001. 
[14] Vikør, K. S. (2014) Sharī'ah, The Oxford Encyclopedia of Islam and Politics. Edited by Emad El-Din Shahin. Oxford: Oxford University Press. 